\title{
Tegnsprogsforskning: Om tegnsprogets bidrag til viden om sprog
}

\author{
Jesper Dammeyer
}

Even through research in sign language is a special field of language research it has contributed with new knowledge about human language because of the visuospatial nature. The article introduces to different issues in sign language research from a cognitive and neuropsychological view. These issues are sign language linguistic, sign aphasia, the neural organization of sign language, signed short-term memory, and the study of speech errors in sign language. The overall purpose of the article is to examine the structure and organization of sign language in comparison to oral language. What linguistic, neural and cognitive similarities and differences are there between signed and oral languages? The article demonstrates that the linguistic, cognitive and neural basis for signed languages overall is similar to oral languages. The similarity of signed and oral languages indicates an amodal cognitive organization of human language.

\section{Indledning}

Med god grund har man i sprogforskningen haft interesse for tegnsprog, da flere aspekter af sprog og sprogudvikling kan belyses ved at studere tegnsprog. Nogle af de sprogvidenskabelige spørgsmål, som har haft interesse, er: Tilegnes tegnsprog på samme måde som oralt sprog? Hvordan er tegnsprogets lingvistiske karakter? Hvordan påvirker brug af tegnsprog personens kognitive funktioner som f.eks. opmærksomhed? Denne artikel vil have fokus på den kognitive og neuropsykologiske ${ }^{1}$ side af tegnsprogsforskningen med fokus på, om det neurale grundlag for tegnsprog er det samme som for oralt sprog, eller om der er nogle særlige forskelle. Denne diskussion er interessant, da den giver viden om det neurale grundlag for sprog mere generelt. Artiklen er således en introduktion til og et review af den neurovidenskabelige tegnsprogsforskning, samt en diskussion af almene forhold vedrørende sprog, bl.a. 


\section{Tegnsprogsforskning}

sprogets plasticitet, adskillelsen mellem sprog og perception, opmærksomhed mv.

Tegnsprogsforskning er et stort område, hvorfor denne artikel kun overfladisk kan præsentere aktuelle diskussioner og aktuel viden. Tegnsprogsforskning foregår i Danmark, bl.a. på Center for Tegnsprog (University College Copenhagen), Københavns Universitet (ved især Elisabeth Engberg-Petersen) og Aarhus Universitet (ved Julie Hansen).

Tegnsprogsbrugere knytter sig ofte socialt til en "døvekultur" (Deaf Community), hvor tegnsproget fungerer som kulturbærende (Schick et al. 2005). Selvom døves kultur er tæt knyttet til tegnsproget og tegnsprogsforskningen, vil dette tema ikke blive behandlet yderligere i denne artikel.

I artiklen gives en række eksempler fra dansk tegnsprog. Da tegnsprog udføres visuospatialt, kan det selvsagt være svært at gengive tegnsprog med dansk skriftsprog. I artiklen er der derfor indsat links til Ordbog over Dansk Tegnsprog, hvor eksemplerne kan ses udført ved små videoklip. For de læsere som ikke i forvejen kender dansk tegnsprog, anbefales det at følge disse links. Der er tradition for at skrive tegnsproglige tegn med store bogstaver, hvorfor det også gøres i denne artikel.

Det er tilstræbt, at artiklen er baseret på den nyeste forskning inden for området, men da der er tale om et lille forskningsområde, er nogle af referencerne af lidt ældre dato. Før de kognitive og neuropsykologiske aspekter af tegnsprogsforskningen behandles, introduceres til tegnsprog og tegnsprogs lingvistiske træk.

\section{Lingvistiske trak ved tegnsprog}

Tegnsprog er lingvistisk fuldt ud selvstændige sprog, som overføres fra generation til generation og varierer geografisk. F.eks. er der forskel på dansk, britisk og amerikansk tegnsprog m.h.t. semantik, syntaks og "fonologi". De lingvistiske træk ligner dog hinanden så meget, at de i denne redegørelse tages under ét. Tegnsprog adskiller sig således fra kommunikationsformer som tegnstøttet kommunikation (hvor dansk tale ledsages af tegn), tegn til tale og andre blandingsformer (pidginformer) mellem tegnet og oralt sprog, som ikke har selvstændige lingvistiske strukturer (Corina 1998).

Udviklingsmæssigt følger det døve barns tilegnelse af tegnsprog som modersmål de oralt baserede sprog med pludren, rækkefølgen for tilegnelse af "fonemer", morfemer, sætningsstruktur mv. (Brenda et al. 2005; Rodda \& Grove 1987; Rönnberg et al. 2000). 


\subsection{Tegnsystemer}

Der kan skelnes mellem forskellige tegnsystemer for visuelt sprog og kommunikation. Her kan de væsentligste nævnes:

- $\quad$ Tegnsproglige tegn. Tegn som indgår i tegnsprog, f.eks. tegnet for MOR, hvor pegefingeren bevæges over panden (se figur 1). Tegnet er i dette tilfælde arbitrært, dvs. der er ingen logisk eller konkret kobling til betydningsindholdet. Andre tegn er ikoniske, f.eks. tegnet BIL som angiver at man holder på et rat.

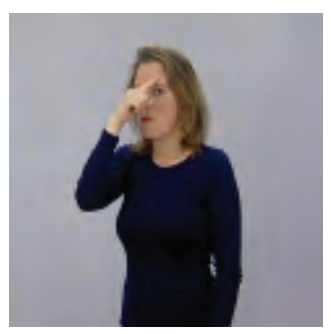

Figur 1. Tegnet for MOR. Se tegnet blive udført på Ordbog over Dansk Tegnsprog (følg linket): http://www.tegnsprog.dk/\#\%7Csoeg\%7C'tekst'mor\%7Cresultat\%7C42 \%7Ctrestjerner\%7C1\%7Ctegn \%7C305

Dog findes der også andre, typisk mere supplerende, tegnsystemer til enten oralt eller tegnet sprog (med tegnet sprog menes tegnsprog). Med relevans for dansk tegnsprog vil jeg her præsentere håndalfabetet og mund-hånd-systemet.

- $\quad$ Håndalfabetet (se figur 2): Internationalt system af fingerstillinger der repræsenterer bogstaverne $i$ alfabetet. Håndalfabetet bruges i tegnsprog til at stave egennavne og til at lave "afledte tegn" (f.eks. tegnet for tirsdag som er håndalfabetets " $\mathrm{t}$ " og “i”) (Engberg-Petersen 1998).

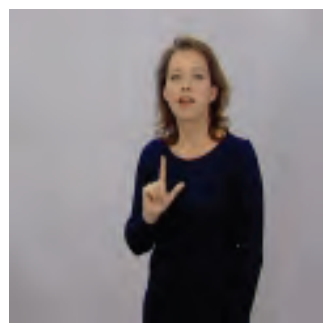

Figur 2. "L" i det internationale håndalfabet. Se tegnet udført her: http://www.tegnsprog.dk/\#\%7Csoeg\%7C'tekst'l\%7Cresultat\%7C5\%7Ctrestjerner\%7C4\%7Ctegn \% $\underline{C 2376}$ 


\section{Tegnsprogsforskning}

- $\quad$ Mund-hånd-systemet (se figur 3): Et særligt dansk system (der findes enkelte lignende systemer i andre lande) (Rodda/Grove 1987), som kombinerer hånd- og fingerstillinger for svært (mund)aflæselige fonemer med mundstillinger. Der er således tale om en kombination af oralt og tegnet sprog (f.eks. ved ordet “øl” markeres ø-lyden med mundstilling og 1 støttes med fingerstilling.).

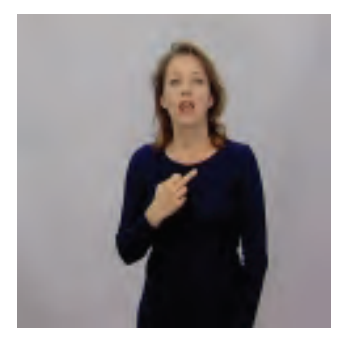

Figur 3. "L" lyden i Mund-hånd-systemet. Se tegnet her: http://www.tegnsprog.dk/\#\% 7Csoeg\%7C'tekst'l\% 7Cresultat\%7C5\%7Ctrestjerner\%7C4\%7Ctegn\%7C893

Selvom oralt og tegnet sprog er forskellige sprog, påvirkes tegnsprog en del af orale sprog. Påvirkningen sker på flere måder: 1) Der er intet skriftsprog knyttet til tegnsprog. For døve bliver skriftsproget det orale skriftsprog, som er dominerende i den flertalskultur hvor de lever. ${ }^{2}$ 2) Mund-hånd-systemet og håndalfabetet, som er integrerede tegnsystemer i tegnsproget, er lyd/skriftbaseret. 3) Der er ingen skarp grænse mellem at være hørende, tunghør og døv (Corina 1998). Mange har en funktionel hørerest, selvom de betegner sig som døve. 4) Ligeledes kan høretabet også være indtrådt sent i livet efter sprogtilegnelsen (postlingvistisk døvhed). 5) Endelig er døve præget af en hørende omverden gennem bl.a. familie, arbejdsplads, medier mv.

\subsection{Lingvistikken}

De centrale lingvistiske forskelle mellem tegnet og oralt sprog er anvendelsen af det tredimentionale rum omkring tegneren (den der udfører tegnsproget) - samt hånd/arm/fingerstilling og bevægelse i stedet for lyde i den "fonetiske" struktur (Rodda \& Grove 1987). Tegnsprogets lingvistiske struktur er unikt, kompliceret og endnu ikke fuldt afdækket (Engberg-Petersen 1998), men grundlæggende gælder det, at tegnsprog kan sættes ind i en lingvistisk struktur ligesom alle andre sprog. Dette kræver uddybning: 
Tegnfonologi: Bevægelse, lokalisation og håndstilling er tegnenes byggesten og svarer til fonemerne ved oralt sprog. Ved variation af et af disse tegnfonemer kan den semantiske betydning skifte (Engberg-Petersen 1998). Se figur 3 for illustration.
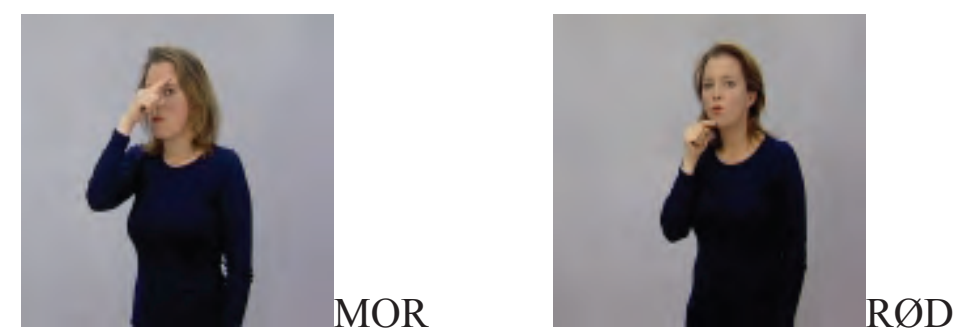

Figur 3. Tegnet for hhv. MOR og RØD er differentieret ved bevcegelsessted og retning. For videovisning følg linkene: MOR (se link ved figur 1) og RØD: http://www.tegnsprog.dk/\#\%7Csoeg\%7C'tekst'r\%C3\%B8d\%7Cresultat\%7C31\%7Ctrestjerner\%7C1 \%7Ctegn\%7C14

Tegnmorfologi: Morfologien ved tegnsprog er rig og kompleks. Et tegn kan f.eks. moduleres grammatisk, så det f.eks. angiver "give til én person", "give til mange", "give gentagne gange" mv. (Rodda \& Grove 1987). Se disse to eksempler på at give til hhv. én og mange personer på følgende link: "Jeg har bare lyst til at give en gave" og "Hun gav alle børnene flødeboller": http://www.tegnsprog.dk/\#\%7Csoeg\%7C'tekst'give\%7C resultat $\% 7 \mathrm{C} 42 \% 7 \mathrm{Ctrestjerner} \% 7 \mathrm{C} 2 \% 7 \mathrm{Ctegn} \% 7 \mathrm{C} 431$. (Sætningerne vælges til højre).

En del af den leksikale morfologi ved tegnsprog kan illustreres med "classifier systemet" (Corina 1998), som i dansk tegnsprogslingvistik kaldes "proformer" (Engberg-Petersen 1998). Dette kan f.eks. være en V-proform (to fingre nedad) som f.eks. repræsenterer et menneske. Som eksempel kan tages, "Der var mange mennesker, men heldigvis fandt jeg en parkeringsplads til bilen". Her bruges en b-proform (flad hånd som $\mathrm{b}$ i håndalfabetet) der henviser til bilen der kører ind i parkeringsbåsen. Se videofremvisningen her (vælg sætningen til højre): http://www.tegnsprog.dk/\#\%7Csoeg\%7C'tekst'k\%C3\%B8re\%7Cresultat\%7 7 C35\%7 Ctrestjerner\%7C9\%7Ctegn\%7C579. Der er faste og komplicerede regler for, hvordan proformer bruges (Engberg-Petersen 1998).

Et andet træk ved morfologien er brugen af ansigtsudtryk. Ansigtsudtryk bruges som faste sproglige udsagn med grammatisk funktion (Corina 1998), og er altså ikke kun nonverbalt kropssprog. F.eks. angives spørgsmål og negation med ansigtsudtryk (Engberg-Petersen 


\section{Tegnsprogsforskning}

1998). Se f.eks. sætningen, "Hvad hedder de der tasker med hjul?" her: http://www.tegnsprog.dk/\#\%7Csoeg\%7C'tekst'hvad\%7Cresultat\%7C99\%7Ctr estjerner\%7C1\%7Ctegn\%7C352. (Sætningen vælges til højre).

Tegnsyntaks: Den grammatiske relation udtrykkes ved tegnrækkefølgen og ved morfologiske bøjninger (Corina 1998). Brugen af rum eller "lokalisation" er vigtig (Engberg-Petersen 1998). I en del orale sprog bruges sætningsstruktur og præpositioner til at angive handlesammenhænge, som f.eks. "Drengen sprang over hunden". Den tidslige rækkefølge angiver, at det er drengen og ikke hunden, der springer, og "over" angiver det rumlige forhold. Ved tegnsprog angives dette alene ved "tegning" i rummet. Hunden repræsenteres af den ene hånd som holdes stille, mens den anden repræsenterer drengen ( $\mathrm{V}$-proform for menneske), der samtidig udfører tegnet "springe" ved en bevægelse hen over "hunden". Se tilsvarende sætningen, "Vi legede med bold. Jeg kastede bolden over garagetaget, og hun greb den på den anden side og kastede den tilbage. " på følgende link: http://www.tegnsprog.dk/\#\%7Csoeg $\% 7 \mathrm{C}$ 'tekst' over $\% 7$ Cresultat $\% 7 C 106 \% 7$ Ctrestjerner $\% 7 \mathrm{C} 2 \% 7$ Ctegn $\% 7 \mathrm{C} 860$.

Som det fremgår af denne korte præsentation, har tegnsprog samme lingvistiske elementer som orale sprog, men med særlige karakteristika formet af det visuo-spatielle tegnrum (Slobin 2005).

Efter denne introduktion til tegnsproget, vil jeg nu tage fokus på de neurolingvistiske aspekter ved tegnsproget. Her vil det fremgå, at tegnsproget også neurobiologisk er organiseret som orale sprog.

\section{Tegnsprogsafasi}

Der er beskrevet en række cases med tegnsprogsafasi. Her ses et mønster, der stemmer overens med de kendte afasier ved talt sprog, hvad angår både flydende og ikke-flydende afasi (Corina 1998; Hickok \& Bellugi 2001). Tilsvarende orale sprog, kan der, lidt groft opdelt, konstateres dysfunktioner på fonetisk-, tegn- og sætningsniveau ved skader i venstre hemisfære (VH), mens skader i højre hemisfære $(\mathrm{HH})$ overvejende medfører diskursive og para-lingvistiske dysfunktioner (Hickok et al. 1999; Hickok/Bellugi 2001; Newman et al. 2010). Der kan gives et par eksempler på opdelingen mellem de to hjernehemisfærer.

\subsection{Lingvistisk og ikke-lingvistisk motorisk dissociation}

I en række tilfælde findes dissociation (dvs. adskilt funktion/organisering) mellem afasi og egentlig apraksi hos tegnsprogsbrugere. Der 
er kliniske tilfælde (VH skadede), hvor patienten har ekspressiv afasi for tegn, men stadig kan gøre brug af gestus og fagter. Dvs. personen kan f.eks. ikke tegne tegnet MOR, men kan godt pege og vinke (hvis det ikke er en del af en sproglig ytring). Det modsatte er også fundet (Corina et al. 1992), dvs. at personen kan udføre tegn, men ikke gestus (ved skade i HH). Sammenholdt med en række andre undersøgelser indikerer dette, at der er forskel mellem lingvistisk og ikke-lingvistisk motorisk funktion, Dvs. tegnsprogsproduktion er overvejende lokaliseret i sprogområder i VH og adskilt fra anden motorisk funktion.

\subsection{Lingvistisk og ikke-lingvistisk visuospatial dissociation}

Tegnsproget påvirkes ikke af venstre-sidig neglekt (dvs. manglende opmærksomhed på lammet venstre side ved skade i HH). Selvom der ikke er objektgenkendelse, er der leksikal tegn-identifikation i det område, der er ramt af neglekt. Dvs. personen vil f.eks. have neglekt for genkendelse af en kop, men vil stadig aflæse tegnet KOP. (Corina et al. 1996; Hickok et al. 1996; Rönnberg et al. 2000). Der findes ligeledes dissociation mellem produktion af ansigtsudtryk med og uden lingvistisk indhold (Rönnberg et al. 2000) ved læsion i hhv. VH og HH (Corina et al. 1999). Dette indikerer en dissociation mellem et verbalt og et nonverbalt visuospatialt system (Corina 1998). M ed andre ord er tegnsproget overordnet set organiseret i sprogområderne i VH og ikke i visuospatiale områder i $\mathrm{HH}$.

\section{Funktioner i højre hemisfære}

Ved brug af billeddannelsesteknik (primært PET- og fMRI-scanning) af normale tegnsprogsbrugere (dvs. uden hjerneskade) ses overordnet aktivering i samme områder som ved oralt sprog (Werniche og Broca i VH) (Emmorey et al. 2003; Hickok \& Bellugi 2001; Horwitz et al. 2003), hvilket bekræfter de kliniske data som omtalt ovenfor. Der findes overordnet, ligesom ved talt sprog, dobbelt dissociation mellem egentlige afasier (VH-skade) og diskursive dysfunktioner (HH skade) (Hickok et al. 1999; Hickok \& Bellugi 2001). Selvom det overordnede billede er tydeligt, er der alligevel på baggrund af billeddannelsesstudier fremkommet hypoteser om, at HH er ansvarlig for særlige lingvistiske karakteristika ved tegnsprog. HH skadede tegnsprogsbrugere har

ikke alene problemer med at lave fortælleforløb, men også med brug af rumlige elementer i tegnsproget (Hickok \& Bellugi 2001) som bl.a. lokalisation (brug af rum). F.eks. er det svært for patienter med neglekt at beskrive indretningen af en stue (Hickok \& Bellugi 2001; Corina et al. 


\section{Tegnsprogsforskning}

1996). Ligeledes kan brugen af proformer være ramt (Emmorey et al. 2002). F.eks. er det svært for HH-skadede at beskrive to biler, der kører frontalt sammen (vandret B-proform i begge hænder ført mod hinanden), ligesom håndstillingerne $\mathrm{i}$ proformerne generelt er simplificerede (Hickok \& Bellugi 2001). Dette underbygges af billeddannelsesdata fra normale tegnsprogsbrugere, hvor $\mathrm{HH}$ er mere aktiv, når der udtrykkes rumlige relationer (Emmorey et al. 2002), og når der bruges proformer (Corina 1998).

Overordnet findes der altså en funktionel opdeling mellem de to hjernehemisfærer som svarer til oralt sprog, men mere detaljerede billeddannelsesstudier har peget på nogle forskelle. Spørgsmålet er dog stadig, om disse afvigelser kan forstås som para-lingvistiske (MacSweeney et al. 2008; Newman et al. 2010). Der beskrives cases, hvor patienten kan erstatte proformer og lokalisering i rummet med andre udtryksmåder på tegnsprog efter en skade (Corina 1998). Emmorey og kolleger (2002) fandt ved PET en forskel på, om proformerne bruges som præpositioner eller som angivelse af genstande i rummet. VH findes mere ansvarlig, når proformer bruges som præpositioner - dvs. har egentlig lingvistiske karakter - modsat spatiale markeringer som aktiverer $\mathrm{HH}$ parietalt. Det kan altså diskuteres, om der er tale om lingvistiske træk eller særlige spatiale funktioner, som kan få lingvistisk karakter i tegnsproget. Aktiveringen i HH behøver ej heller at være særlig for tegnsprog, idet der ved talt sprog også findes aktivering i HH ved brug af forholdsord (Emmorey et al. 2002). Nyere forskning peger på en mere kompleks organisering af sprog i de to hjernehemisfærer (Newman et al. 2010).

\section{Betydningen af tegnsprog som modersmål}

Tegnsprog kan være modersmål, hvor barnet enten er hørende med døve tegnsprogede forældre eller døvfødt med enten døve eller hørende forældre. Tegnsproget kan også være tilegnet som andetsprog, f.eks. hos hørende familiemedlemmer til en døv tegnsprogsbruger. Om tegnsprog er modersmål eller andetsprog, og om modersmålstegneren er døv eller hørende, har betydning for specialisering af områder i både $\mathrm{HH}$ og VH. Disse forskelle kan bl.a. bidrage med viden om plasticiteten i de neurale sprogområder. Jeg vil her kort redegøre for dette forskningsområde, for at vise et af de mange andre områder, som er af interesse i den neurovidenskabelige tengsprogsforskning.

Newman et al. (2002) fandt ved skanning (fMRI) aktivering $i$ et område i HH (sulcus temporalis superior) ved tegnperception, men kun hos personer, som havde tillært tegnsprog sent. Noget lignende fandt 
MacSweeney et al. (2002) i et område i VH (gyrus temporalis superior) ved tegnperception hos døve sammenlignet med hørende modersmålstegnere. Også ved tegnproduktion findes der forskelle. Områder i HH findes kun aktive (gyrus angularis i den inferiore parietale kortex og præmotorisk kortex) hos modersmålstegnere (Newman et al. 2002) og ikke hos personer som har lært tegnsprog sent. Resultaterne vidner om, at andre forhold end tegnsprogets visuospatielle karakter spiller ind på sprogets organisering.

De nævnte fund er dog ikke entydige. Billeddannelsesdata fra orale sprogbrugere viser også uoverensstemmende HH-aktivering (Mayberry 2003), ligesom flere undersøgelser ikke finder forskel i HH mellem døve og hørende (Levanen et al. 2001; MacSweeney et al. 2002) eller variation ift., om tegnsprog er tillært sent eller tilegnet som modersmål (Bavillier et al. 1998). De kliniske fund af afasi støtter dette billede, idet der ikke findes variation i skadernes karakter afhængig af grad af høretab eller alder for tilegnelse af tegnsprog (Hickok \& Bellugi 2001). Som antydet her er tosprogethedsforskning interessant, også når det angår to modaliteter. Resultaterne fundet ved tegnsprog er på flere måder i tråd med tosprogethedsforskning af to orale sprog. Her tegner der sig også et komplekst billede.

\subsection{Tidlig tilegnelse af sprog og psykisk udvikling}

Forskning omkring børn med medfødt høretab finder, at det har stor betydning for barnets psykiske udvikling (kognitivt, social mv.), at det fra fødslen tilbydes et sprogligt og kommunikativt miljø, der er godt nok. F.eks. er der forsket en del i udviklingen af Theory of Mind (evnen til at danne sig forestillinger om en anden persons tanker, følelser mv.), og hvordan denne påvirkes af medfødt høretab (Mayberry 2003). Theory of Mind tages her som eksempel på et af flere relevante temaer relateret til sprogudvikling belyst gennem tegnsprogsforskning. Gennemgående udvikles evnen til Theory of Mind senere hos døve børn, hvilket ser ud til at hænge sammen med de sproglige/kommunikative vanskeligheder. Døve børn som er i et tegnsprogmiljø fra fødslen og udvikler tegnsprog som modersmål, har ikke senere tilegnelse af Theory of Mind (Meristo et al. 2007; Peterson 2004; Courtin \& Melot 1998; Peterson \& Siegal 1999). Det ser ud til, at udvikling af et velfungerende sprog er en del af forudsætningen for at kunne sætte sig ind i et andet menneskes tanker og følelser og kunne forstå, at de kan være forskellige fra ens egne. Forskningen peger derved på, at det er sprog og kommunikation, der er det kritiske omdrejningspunkt, snarere end graden af høretab. Hvad angår 


\section{Tegnsprogsforskning}

sprog, kognition og social udvikling, så udvikler døve børn sig i store træk som hørende børn, hvis deres adgang til tegnsprog er "god nok", og de ikke har andre funktionsnedsættelser end høretabet (Marschark \& Spencer 2003; Mayberry 2003; Dammeyer 2010). Flere studier viser, at døve børn af døve forældre, som kan tegnsprog, udvikler sig bedre end døve børn af hørende forældre, som ikke kan tegnsprog (Meadow 2005; Hindley 2000; Meadow-Orlans 1987; Mayberry 2003). Alt i alt er der flere resultater, der overbevisende peger på, at den tidlige tilegnelse af sprog er betydningsfuld.

\section{Tegnefejl (udtalefejl ved tegnsprog) versus talefejl}

Studiet af udtalefejl er endnu en måde at studere tegnsproget på og sammenligne det med orale sprog. Hos normale (ikke afatiske) tegnsprogsbrugere optræder samme fejltyper ved tegnet og oralt sprog (Corina 1998; Jay 2003). Der er typisk motorisk lighed ved tegnefejl svarende til fonetiske fejl (eller syllabiske fejl) ved talt sprog (Jay 2003). Endvidere ses semantiske ombytninger, som også findes ved talt sprog.

Ved afasier ses også samme typer af talefejl som ved oralt sprog. Fonetiske parafasier ses som ombytning af håndstilling, lokalisation, bevægelse og orientering - hvor ombytning af håndstilling er typisk (Corina 1998). Morfologiske og syntaktiske fejl ved afasier stemmer også overens med agrammatisme og paragrammatisme ved talt sprog. Der kan være udeladt eller ombyttet bevægelsesform ved verber ${ }^{3}$, ombyttet eller udeladt (lingvistisk) ansigtsudtryk m.fl. (Corina 1998). Disse fund ved tegnefejl indikerer overensstemmelse mellem kognitive processer for produktion af tegnet og oralt sprog, og at de samme kognitive modeller er gældende.

Da sætninger på tegnsprog opbygges som visuospatiale helheder og ikke kun præsenteres som fonetiske elementer i kronologisk rækkefølge, må det formodes, at der kognitivt gøres brug af både top-down og bottom-up processer. ${ }^{4}$

\section{Hukommelsesfunktionen hos tegnsprogsbrugere}

Generelt findes der ikke forskelle i de kognitive funktioner mellem døve og hørende (Mayberry, 2003). I litteraturen har der dog været en interesse for, om døve udvikler særlige kognitive evner, og enkelte studier har peget på en bedre ansigtshukommelse hos modersmålstegnere, bedre evne til mental rotation og perifer opmærksomhed (Rönnberg et al. 2000). En anden og mere væsentlig forskel er fundet ved en mindre hukommelsesspændvidde hos døve sammenlignet med hørende (Mayber- 


\section{Jesper Dammeyer}

ry 2003; Rodda \& Grove 1987). Jeg vil her redegøre for denne forskel, da den bidrager til den neurovidenskabelige viden om sprog mere generelt. De seneste år er hukommelsen hos tegnsprogsbrugere forsøgt forstået i arbejdshukommelsesmodellen (Working Memory (WM)) (Baddeley 1996). Arbejdshukommelsen er et hukommelsessystem som vedligeholder og lagrer information (korttidshukommelse). Dette hukommelsessystem består af en central styreenhed kaldet den "centrale eksekutivfunktion" og to slavesystemer: "den fonologiske sløjfe" (som har til opgave at opbevare talte ord i den rigtige rækkefølge) og den "visuospatiale skitseblok" (som har til opgave at opbevare og manipulere rumlig og visuel information) (Baddeley, 2003). Der er desuden senere tilføjet en fjerde komponent kaldet den episodiske buffer, som er et bindeled mellem arbejdshukommelsen og langtidshukommelsen (Baddeley 2003). I det følgende vil jeg redegøre for en "tegn-sløjfe" ved tegnet sprog svarende til fonologisk sløjfe ved talt sprog.

\subsection{En tegn-sløjfe som fonologisk sløjfe i arbejdshukommelsen}

WM-modellen giver anledning til overvejelser om, hvordan tegnsprogsbrugere holder sprogbaseret materiale i WM, idet de umiddelbart ikke kan gøre brug af den fonologiske sløjfe. Wilson \& Emmorey (1997) har undersøgt dette og fandt, at den fonologiske sløjfe også fungerer ved tegnet sprogmateriale..$^{5}$ Dette godtgør, at WM funktionen er "ens" for tegnsprogsbrugere og orale sprogbrugere. Der gøres altså ved tegnsprog ikke brug af et visuospatialt hukommelsessystem i HH (f.eks. den visuospatiale skitseblok) (Baddeley 1996), men et sprogbaseret i VH (svarende til fonologisk sløjfe) (Marschark/Mayer 1998; Rönnberg et al. 2000). ${ }^{6}$

Billeddannelsesdata (McGuire et al. 1997) har fundet samme aktivering ved "indre tegnet" og "indre talt" sprog (lokaliseret i præmotorisk kortex i VH). Disse resultater underbygger ovenstående, da den fonologiske sløjfe menes at være knyttet til indre sprog (Baddeley 1996) og er i tråd med opdelingen mellem HH og VH som beskrevet ovenfor. ${ }^{7}$

\section{Skift mellem sprogkoder}

Funktionelt viser det sig, at der ikke er skarpe skel mellem tegnet og oralt sprog. Undersøgelser viser, at mange døve kan skifte mellem en fonetisk (talebaseret) kodning og en visuospatial (tegnbaseret) kodning, afhængig af den kommunikative kontekst (Rodda \& Grove 1987; Alford \& Enerstvedt 1997; Mayberry 2003). Skal der f.eks. løses en rumlig op- 


\section{Tegnsprogsforskning}

gave (en samleanvisning til en reol) tænkes der på tegnsprog, mens der tænkes på dansk ved mere sproglige opgaver (løse en kryds og tværs). Alford \& Enerstvedt (1997) har vist, at der også findes en rimeffekt hos døve - dog svagere end hos hørende (Hanson 1990 i Alford \& Enerstvedt 1997) (dvs. dårligere genkaldelse af skriftligt præsenterede fonetisk ens og visuelt forskellige ord end fonetisk forskellige ord). Selvom døve bruger en visuel strategi, kan de altså "presses" til eller "vælge" at kode fonetisk (Hanson 1990 i Alford \& Enerstvedt 1997). Døve kan altså gøre brug af en indre fonetisk fastholdelse af materiale, hvis det er fordelagtigt (Rodda \& Grove 1987; Alford \& Enerstvedt 1997). Den

fonetiske kodning kan skyldes, at tegnsprogsbrugeren bliver påvirket af oralt sprog, som tidligere redegjort for. Tegnsprogbrugere er typisk så påvirket af en oralsproglig omverden, at de ofte skifter mellem dansk sprogkode, tegndansk (blandingsform) og egentlig tegnsprog. Selvom tegnsprog er forskellig fra orale sprog, ser det ud til, at der er store funktionelle overlap. Igen er konklusionen, at selvom der er tale om forskellige modaliteter, fungerer det humane sprog tvær- og amodalt.

\section{Opsamling}

Overordnet findes der ingen væsentlige forskelle mellem oralt og tegnet sprog (Macsweeney et al. 2008). Dette indikerer et amodalt humant sprogsystem, dvs. sproget er ikke styret/formet af lydperception og -produktion. Den overordnede lighed mellem tegnet og oralt sprog sandsynliggøres ved forskellige forskningsområder og metoder som gennemgået: Lingvistiske studier, studier af patienter med afasi, billeddannelsesdata og kognitive undersøgelser.

Dog er der, som vist, funktionelle forskelle. Det billede der samtidig tegnes er, at de lingvistiske, neurale og kognitive strukturer for sprog er fleksible/plastiske, det humane sprog kan tilpasses tegnsprogets visuospatiale karakter, Undersøgelsernes resultater findes ofte afhængige af, om tegnsprog er modersmål, om tegneren er døv eller hørende, om barnet med medfødt døvhed har været sprogdepriveret de første leveår mv., hvilket demonstrerer miljøets samspil med den sproglige udvikling. At tegnsprogsbrugere ofte reelt fungerer som tosprogede og kan skifte mellem fonetisk og tegnet kodning afhængig af opgave og situation, fortæller ligeledes om en fleksibilitet ved det humane sprog.

Som udgangspunkt kan tegnsprog studeres som ethvert andet sprog, hvad angår lingvistik, sprogudvikling, sprogforstyrrelser og afasi. Der er basis for meget interessant sprogforskning, også om dansk tegnsprog. 


\section{Jesper Dammeyer}

\section{Noter}

1 Neuropsykologi beskæftiger sig med forholdet mellem hjernen og de psykiske funktioner, her sprog.

2 Forsøg på at lave tegnskrift (ikoniserede gengivelser af tegn) har ikke slået igennem.

3 Verber adskilles ofte fra subjekter alene ved en mere blød bevægelsesform. F.eks. "kører" og "bil".

4 Dette stemmer overens med flere kognitive modeller for sprog. "Connectionistiske modeller" for sprogforståelse peger netop på parallelle bottom-up og top-down processer på fonem og ordniveau, modsat modeller, hvor sprogidentifikation forstås som kronologiske forløb. (F.eks. TRACE-modellen (McClelland/Rumelhart 1981 i Eysenck/Keane 1995) over for Cohort theory (Marslen-Wilson/Tyler 1980 i Eysenck/Keane 1995)).

5 De undersøgte dette ved oversættelse af de "klassiske WM forsøg" til tegnet sprog. En gruppe af døve blev således undersøgt for seriel genkaldelse ved "artikulatorisk suppression" og "tegn-ligheds-effekten" (svarende til similarity-effect). (genkaldelse af ikke semantisk tegn og genkaldelse af tegn med motorisk lighed - d.v.s. tegn med samme håndform, som kun varierer ved bevægelsesretning og lokalisation.) Effekterne blev fundet svarende til talt sprog, hvilket vil sige, at evnen til genkaldelse falder, ligesom de to effekter ikke interagerer (Wilson/Emmorey 1997).

6 Dette taler for en revision af forståelsen af den fonologiske sløjfe i Baddeleys model, da denne så ikke er modalitetsspecifik (fonologisk), men snarere sprogbaseret (lingvistisk) (Wilson/Emmorey 1997).

7 Ordlængdeeffekten findes også ved tegnsprog i lighed med oralt sprog (Wilson/Emmorey 1997), dvs. jo "længere" tegnene er, jo færre kan der rummes i WM (Rönnberg et al. 2000). Dette giver sandsynligvis forklaringen på, hvorfor man har fundet en mindre hukommelsesspændvidde hos døve sammenlignet med hørende (Rodda/Grove 1987), idet det tager længere tid at tegne tegn end at tale ord (Rodda/Grove 1987, Rönnberg et al. 2000, Mayberry 2003).

\section{Litteratur}

Alford, S. M. \& R. T. Enerstvedt (1997). "Indre språk. Med hovedvekt på indre tale - belyst ved spørsmålet om døves indre språk”, Publication Series No. 4., Oslo: Skådalen kompetansesenter.

Brenda, S., M. Marschark \& P. E. Spencer (eds.) (2005). Advances in the SignLanguage Development of Deaf Children, New York: Oxford University Press.

Baddeley, A. (1996), Human Memory. Theory and practice, London: Erlbaum. 


\section{Tegnsprogsforskning}

Baddeley, A. (2003). "Working Memory: looking back and looking forward", Nature Reviews Neuroscience, 4 (2003):829-839.

Bavillier, D., D. Corina, P. Jezzard, V. Clark, A. Karni \& A. Lalwani (1998). "Hemispheric specialization for English and ASL: left invariance-right variability”, Neuroreport, 9 (7) (1998):1537-1542.

Corina, D., H. Poitzner, U. Bellugi, T. Feinberg, D. Dowd \& L. O'Grady Batch (1992). "Dissociation between linguistic and nonlinguistic gestural systems: a case for compositionality", Brain and Language, 43 (1992):1258-1260.

Corina, D. (1998), “Aphasia in Users of Signed Languages". In: P. Coppers et al. (eds.) (1998). Aphasia in Atypical Populations, Mahwah: Lawrence Erlbaum:261-310.

Corina, D., M. Kritchevsky \& U. Bellugi (1996). "Visual language processing and unilateral neglect: Evidence from American Sign Language", Cognitive Neuropsychology, 13 (3) (1996):321-356.

Corina, D.P., U. Bellugi \& J. Reilly (1999). "Neuropsychological studies of linguistic and affective facial expressions in deaf signers", Language and Speech, 42 (2-3):307-331.

Courtin, C. \& A.M. Melot (1998). "Development of Theories of Mind in Deaf Children”. In M. Marschark \& M. D. Clark (eds.) (1998), Psychological Perspectives on Deafness, Vol. 2. Mahwah, New Jersey: Lawrence Erlbaum:79-102.

Dammeyer, J. (2010). "Psychosocial development in a Danish population of children with cochlear implants and deaf and hard of hearing children." Journal of Deaf Studies and Deaf Education. 15 (1) (2010):50-58.

Emmorey, K., T. Grabowski, S. McCullough, H. Damasio, L. L. B. Ponto, R. D. Hichwa \& U. Bellugi (2002). "Neural Systems Underlying Spatial Language in American Sign Language", NeruroImage, 17 (2002):812-824.

Emmorey, K., T. Grabowski, S. McCullough, H. Damasio, L. L. B. Ponto, R. D. Hichwa \& U. Bellugi (2003). "Neural systems underlying lexical retrieval for sign language", Neruopsychologia, 41 (1) (2003):85-95.

Engberg-Petersen, E. (1998). "Lcerebog i tegnsprogsgrammatik”, Ålborg: Døves Center for Total Kommunikation.

Eysenck, M. W. \& M. T. Keane (1995). “Cognitive Psychology: A Student's handbook" ( $3^{\text {rd }}$ Edition), Hove (UK): Erlbaum.

Hickok, G., K. Say, U. Bellugi \& E. S. Klima (1996). "The basis of hemispheric asymmetries for language and spatial cognition: Clues from focal brain damage in two deaf native signers", Aphasiology, 10 (6) (1996):577-591.

Hickok, G., M. Wilson, K. Clark, E. S. Klima, M. Kritchevsky \& U. Bellugi (1999). "Discourse deficits following right hemisphere damage in deaf signers", Brain and Language, 66 (2) (1999):233-248.

Hickok, G. \& U. Bellugi (2001).“The signs of aphasia” . In: R. S. Brandt (ed.) (2001). Handbook of Neuropsychology, Vol. 3 (2 $2^{\text {nd }}$ Edition), New York \& Oxford: Elsevir:31-50. 
Hindley, P. (2000). "Child and Adolescent Psychiatry". In: P. Hindley \& N. Kitson (eds.) (2000), Mental Health and Deafness, London and Philadelphia: Whurr:42-74.

Horwitz, B., K. Amunts, R. Bhattacharyya, D. Patkin, K. Jeffries, K. Zilles \& K. A. R. Braun (2003). "Activation of Broca's area during the production of spoken and signed language: a combined cytoarchitectonic mapping and PET analysis", Neuropsycholoiga, 41 (2003):1868-1876.

Jay, T. (2003). "The Psychology of Language”, New Jersey: Prentice Hall.

Levanen, S., K. Uutela, S. Salenius \& R. Hari (2001). "Cortical representation of sign language: comparison of deaf signers and hearing non-signers", Cerebral Cortex, 11 (6) (2001):506-512.

MacSweeney, M., C. M. Capek, R. Campbell \& B. Woll (2008). "The signing brain: the neurobiology of sign language", Trends in Cognitive Sciences, 12 (11):432-440.

MacSweeney, M., B. Woll, R. Campbell, P. K. McGuire, A. S. David, S. C. R. Williams, J. Suckling, G. A. Calvert \& M. J. Brammer (2002). "Neural systems underlying British Sign Language and audio-visual English processing in native users", Brain, 125 (7) (2002):1583-1593.

Marschark, M. \& T. S. Mayer (1998). "Interactions of language and memory in deaf children and adults", Scandinavian Journal of Psychology, 39 (3) (1998):145-148.

Marschark, M. \& P. E. Spencer (eds.) (2003). "Deaf Studies, Language, and Education”, Oxford, New York: Oxford University Press.

Mayberry, R. I. (2003). "Cognitive development in deaf children: the interface of language and perception in neuropsychology" . In: Segalowitz, S. J. \& I. Rapin (eds.) (2003). Handbook of Neuropsychology, Vol. 8, Part II, $\left(2^{\text {nd }}\right.$ Edition), New York and Oxford: Elsevier:487-523.

McGuire, P.K., D. Robertson, A. Thacker, A. S. David, N. Kitson, R. S. Frackowiak \& C. D. Frith (1997). "Neural correlates of thinking in sign language", Neuroport, 8 (3) (1997):695-698.

Meadow, K. P. (2005). Early Manual Communication in Relation to the Deaf Child's Intellectual, Social, and Communicative Functioning. Journal of Deaf Studies and Deaf Education, 10 (4) (2005):321-329.

Meadow-Orlans, K. (1987). "Understanding Deafness: Socialization of Children and Youth" . In: P. C. Higgins, \& J. E. Nash (eds.) (1987). Understanding Deafness Socially. Springfield, Illinois: Charles C. Thomas Publisher:29-58.

Meristo, M., K. Falkman, E. Hjelmquist, M. Tedoldi, L. Surian \& M. Siegal (2007). Language Access and Theory of Mind Reasoning: Evidence from Deaf Children in Bilingual and Oral Environments, Developmental Psychology, 43 (5) (2007):1156-1169.

Newman, A. J., D. Bavelier, D. Corina, P. Jezzard \& H. J. Neville (2002). “A critical period for right hemisphere recruitment in American Sign Language processing", Nature Neuroscience, 5 (1) (2002):76-80. 


\section{Tegnsprogsforskning}

Newman, A. J., T. Supalla, P. Hauser, E. Newport \& D. Bavelier (2010). "Prosodic and narrative processing in American sign Language: An fMRI study", Neuroimage, 52 (2):669-676.

Peterson, C. \& M. Siegal (1999). "Representing inner worlds: Theory of mind in autistic, deaf and normal hearing children", Psychological Science, 10 (2) (1999):126-129.

Peterson, C. (2004). "Theory-of-mind development in oral deaf children with cochlear implants or conventional hearing aids", Journal of Child Psychology and Psychiatry, 45 (6) (2004):1096-1106.

Rodda, M. \& C. Grove (1987). Language, Cognition and Deafness, Hillsdale N. J. \& London: Lawrence Erlbaum.

Rönnberg, J., B. Söderfeldt \& B. J. Risberg (2000). "The cognitive neuroscience of signed language", Acta Psychology, 105 (2-3) (2000):237-254.

Schick, B., M. Marschark \& P. E. Spencer (2005). "Understanding Sign Language Development of Deaf Children” I. In: S. Brenda et al. (eds.) (2005). Advances in the Sign-Language Development of Deaf Children, New York: Oxford University Press:3-19.

Slobin, D. I. (2005). "Issues of Linguistic Typology in the Study of Sign Language Development of Deaf Children” I. In: S. Brenda et al. (eds.) (2005). Advances in the Sign-Language Development of Deaf Children, New York: Oxford University Press:20-45.

Wilson, M. \& K. Emmorey (1997). "A visuospatial "phonological loop" in working memory: Evidence from American Sign Language", Memory \& Cognition, 25 (3) (1997):313-320.

Jesper Dammeyer

Institut for Psykologi

Københavns Universitet

jesper.dammeyer@psy.ku.dk 